\title{
HUBUNGAN DUKUNGAN SUAMI DAN KELUARGA DENGAN INTENSITAS NYERI PERSALINAN KALA I
}

\author{
Elika Puspitasari ${ }^{1}$ \\ ${ }^{1}$ Program Studi Kebidanan Program Sarjana Terapan Fakultas Ilmu Kesehatan \\ Universitas 'Aisyiyah Yogyakarta, Indonesia \\ Email: ${ }^{1}$ elikapuspita@unisayogya.ac.id
}

Tanggal Submisi: 23 November 2018; Tanggal Penerimaan: 30 Desember 2019

\begin{abstract}
ABSTRAK
Wanita dalam persalinan kala I didapatkan bahwa 60\% primipara melukiskan nyeri akibat kontraksi uterus sangat hebat, $30 \%$ nyeri sedang. Pada multipara $45 \%$ nyeri hebat, $30 \%$ nyeri sedang, $25 \%$ nyeri ringan. Dukungan suami dan keluarga merupakan faktor eksternal dari support system dapat membantu mengurangi nyeri persalinan. Tujuan penelitian ini adalah untuk mengetahui hubungan dukungan suami dan keluarga terhadap intensitas nyeri persalinan kala I. Desain penelitian menggunakan observasional analitik dengan pendekatan cross sectional. Analisa bivariat menggunakan uji statistik Spearman. Hasil analisa bivariat menunjukkan ada hubungan antara dukungan suami dan keluarga dengan intensitas nyeri persalinan Kala I dibuktikan dengan p-value < 0,05 (0,018). Nilai koefisien korelasi $(-0,396)$ menunjukkan hubungan yang negatif dimana semakin tinggi dukungan suami dan keluarga maka semakin rendah intensitas nyeri persalinan yang dirasakan oleh ibu bersalin. Saran bagi bidan yang bertugas di ruang bersalin khususnya diharapkan dapat memberikan asuhan manajemen nyeri persalinan lebih variatif sehingga ibu bersalin dapat terbantu menemukan koping nyeri yang sesuai.
\end{abstract}

Kata kunci : dukungan suami, nyeri persalinan

ISSN 1979-7621 (Print). ISSN 2620-7761 (Online).

\begin{abstract}
Women in the first stage of labor found that $60 \%$ of primiparas described pain due to uterine contractions being very severe, $30 \%$ moderate pain. In multipara $45 \%$ pain is great, $30 \%$ is a moderate pain, $25 \%$ is the mild pain. Husband and family support is an external factor from the support system can help reduce labor pain. The purpose of this study was to determine the relationship between husband and family support for the intensity of first stage labor pain. The study design used observational analytic with the cross-sectional approach. The bivariate analysis uses the Spearman statistical test. The results of the bivariate analysis showed that there was a relationship between the husband's
\end{abstract}


support and family with the intensity of labor pain in the first stage as evidenced by $\mathrm{p}$-value <0.05 (0.018). The correlation coefficient ($0,396)$ shows a negative relationship where the higher the support of husband and family, the lower the intensity of labor pain felt by the mother. Suggestions for midwives who are in charge of the delivery room are especially expected to be able to provide care for the management of labor pain more varied so that mothers can be helped find appropriate pain coping.

Keywords: husband's support, labor pain

\section{PENDAHULUAN}

Perilaku ibu selama masa kehamilan akan mempengaruhi perilaku ibu dalam mencari penolong persalinan akan mempengaruhi kesehatan ibu dan janin yang dilahirkan. Bidan harus mempertahankan kesehatan ibu dan janin serta mencegah komplikasi pada saat kehamilan dan persalinan sebagai suatu kesatuan yang utuh (Juwita, 2014). Sebuah penelitian dilakukan pada wanita dalam persalinan kala I didapatkan bahwa $60 \%$ primipara melukiskan nyeri akibat kontraksi uterus sangat hebat, $30 \%$ nyeri sedang. Pada multipara $45 \%$ nyeri hebat, $30 \%$ nyeri sedang, 25\% nyeri ringan (Maslikhanah 2011). Nyeri dalam persalinan dapat terlihat dari perubahan sikap, cemas, merintih, menangis, bahkan sampai meraung (Hutahaean, 2009).

Diharapkan dari dukungan
suami yang diberikan akan
menenangkan emosi ibu sehingga
proses persalinan akan dilewati dengan
perasaan senang dan terhindar dari
depresi, dan akan memperkecil nyeri
yang dirasakan ibu saat bersalin. Hal
ini diperkuat oleh pernyataan
Hilmansyah (2011) bahwa dukungan
yang baik akan membantu ibu

menurunkan rasa nyeri yang diderita. Dalam kondisi relaks, tubuh akan memproduksi hormon bahagia yang disebut endorphin yang akan menekan hormon stressor sehingga rasa nyeri yang dirasakan akan berkurang. Dukungan diberikan oleh suami akan membuat ibu lebih nyaman dan lebih menikmati setiap perjalanan persalinan, semakin ibu menikmati proses persalinan maka ibu akan merasa lebih relaks akibatnya ibu tidak lagi terfokus pada rasa nyeri persalinan, sehingga nyeri persalinan tidak lagi terasa. Penelitian ini bertujuan untuk mengetahui hubungan dukungan suami dan keluarga terhadap intensitas nyeri persalinan kala I di RSKIA Ummi Khasanah Bantul.

\section{METODE PENELITIAN}

Penelitian ini menggunakan desain penelitian observasional analitik dengan pendekatan cross sectional. Dalam penelitian ini pengambilan sampel dilakukan dengan teknik insidental sampling. Sampel yang diperoleh selama pelaksanaan penelitian ada $35 \mathrm{ibu}$ bersalin. Alat untuk pengumpulan data pada penelitian ini menggunakan kuesioner dan lembar observasi. Data yang diperoleh berupa data primer untuk 
dukungan suami dan keluarga serta pengukuran nyeri persalinan kala I fas aktif diperoleh melalui observasi. Analisis bivariatnya digunakan uji korelasi Spearman.

\section{HASIL DAN PEMBAHASAN}

\begin{tabular}{lcc}
\multicolumn{3}{c}{$\begin{array}{c}\text { Tabel 1 Distribusi Frekuensi } \\
\text { Karakteristik Responden }\end{array}$} \\
\hline \multicolumn{1}{c}{ Variabel } & $\begin{array}{c}\text { Frekuensi } \\
\text { (n) }\end{array}$ & $\%$ \\
\hline Usia & 8 & 22,9 \\
20-25 tahun & 13 & 37,1 \\
26-30 tahun & 14 & 40 \\
$\quad 31-35$ tahun & 35 & 100 \\
Total & & \\
Paritas & 16 & 45,7 \\
$\quad$ Primipara & 19 & 54,3 \\
$\quad$ Multipara & 35 & 100 \\
Total & & \\
Pendidikan & 9 & 25,7 \\
Rendah & 26 & 74,3 \\
Tinggi & 35 & 100 \\
Total & & \\
\hline Pengalaman nyeri & 16 & 45,7 \\
persalinan & 19 & 54,3 \\
$\quad$ Ada & 35 & 100 \\
$\quad$ Tidak ada & & \\
Total &
\end{tabular}

Tabel 1. Menunjukkan usia responden dengan rentang 31-35 tahun sebanyak 14 orang (40\%), mayoritas responden merupakan multipara yaitu 19 orang $(54,3 \%)$, pendidikan dengan klasifikasi tinggi sebanyak 26 orang $(74,3 \%)$, dan 19 orang $(54,3 \%)$ reponden tidak memiliki pengalaman nyeri persalinan sebelumnya.

Tabel 2. menunjukkan skor minimal untuk dukungan suami dan keluarga adalah 9 dan skor maksimalnya adalah 20, dengan nilai rata-rata sebesar 17,20. Variabel tingkat nyeri persalinan kala 1 untuk skor minimalnya 5 , skor maksimalnya 10 , dan nilai rata-ratanya 7,80 .
Uji statistik antar variabel menggunakan Spearman-rho karena data interval tidak terdistribusi normal dimana $p$-value $<0,05$. Uji hipotesis menunjukkan Ho ditolak dan $\mathrm{Ha}$ diterima sehingga dapat disimpulkan bahwa ada hubungan antara dukungan suami dan keluarga dengan intensitas nyeri persalinan Kala I dibuktikan dengan $p$-value $<0,05(0,018)$. Nilai koefisien korelasi (-0,396) menunjukkan hubungan yang negatif dimana semakin tinggi dukungan suami dan keluarga maka semakin rendah intensitas nyeri persalinan yang dirasakan oleh ibu bersalin.

Suami dikatakan mendampingi istri saat persalinan yaitu ketika suami memberikan semua asuhan fisik dan psikologi yang dibutuhkan ibu melalui persalinan secara terus menerus dimulai dari persalinan kala I fase aktif atau dari pembukaan 4 sampai pembukaan 10. Sejalan dengan hasil penelitian Magfuroh (2012) bahwa ibu inpartu membutuhkan asuhan fisik dan psikologi sehingga persalinannya berjalan normal.

Dukungan dari suami dapat ditunjukkan dengan berbagai cara seperti memberikan keteangan pada istri, memberikan sentuhan, mengungkapkan kata-kata yang memacu motivasi istri (Susanti, 2012), semakin banyak pemikiran negatif yang muncul, antara lain takut mati dan merasa bersalah, diharapkan dari dukungan suami yang diberikan ketika persalinan akan dilewati dengan perasaan senang dan terhindar dari depresi, sehingga akan memperkecil rasa nyeri yang dirasakan oleh ibu ketika bersalin. 
Tabel 2. Analisis Univariat Dukungan Suami dan Keluarga, serta Intensitas Nyeri Persalinan

\begin{tabular}{lccccccc}
\hline \multicolumn{1}{c}{ Variabel } & Total & Min & Max & Mean & SD & $\begin{array}{c}\text { Koefisien } \\
\text { Korelasi }\end{array}$ & p-value \\
\hline $\begin{array}{l}\text { Dukungan suami dan } \\
\text { keluarga }\end{array}$ & 35 & 9 & 20 & 17,20 & 3,2 & $-0,396$ & 0.018 \\
\begin{tabular}{l} 
Tingkat nyeri \\
\hline
\end{tabular} & 35 & 5 & 10 & 7,80 & 1,6 & & \\
\hline
\end{tabular}

Uji statistik antar variabel menggunakan Spearman-rho karena data interval tidak terdistribusi normal dimana $p$-value $<0,05$. Uji hipotesis menunjukkan Ho ditolak dan $\mathrm{Ha}$ diterima sehingga dapat disimpulkan bahwa ada hubungan antara dukungan suami dan keluarga dengan intensitas nyeri persalinan Kala I dibuktikan dengan $p$-value $<0,05(0,018)$. Nilai koefisien korelasi (-0,396) menunjukkan hubungan yang negatif dimana semakin tinggi dukungan suami dan keluarga maka semakin rendah intensitas nyeri persalinan yang dirasakan oleh ibu bersalin.

Suami dikatakan mendampingi istri saat persalinan yaitu ketika suami memberikan semua asuhan fisik dan psikologi yang dibutuhkan ibu melalui persalinan secara terus menerus dimulai dari persalinan kala I fase aktif atau dari pembukaan 4 sampai pembukaan 10. Sejalan dengan hasil penelitian Magfuroh (2012) bahwa ibu inpartu membutuhkan asuhan fisik dan psikologi sehingga persalinannya berjalan normal. Dukungan dari suami dapat ditunjukkan dengan berbagai cara seperti memberikan keteangan pada istri, memberikan sentuhan, mengungkapkan kata-kata yang memacu motivasi istri (Susanti, 2012), semakin banyak pemikiran negatif yang muncul, antara lain takut mati dan merasa bersalah, diharapkan dari dukungan suami yang diberikan ketika persalinan akan dilewati dengan perasaan senang dan terhindar dari depresi, sehingga akan memperkecil rasa nyeri yang dirasakan oleh ibu ketika bersalin. Hasil pengisian kuesioner dukungan suami dan keluarga selama mendampingi proses persalinan ibu adalah sebagai berikut :

Tabel 3. Item Kuesioner Dukungan suami dan keluarga

\begin{tabular}{|c|c|c|}
\hline No & Item Kuesioner & $\%$ \\
\hline 1 & $\begin{array}{l}\text { Datang ke klinik bersama } \\
\text { ibu }\end{array}$ & 91 \\
\hline 2 & $\begin{array}{l}\text { Mendampingi ibu selama } \\
\text { Kala I }\end{array}$ & 89 \\
\hline 3 & $\begin{array}{l}\text { Membantu memberikan } \\
\text { makan dan minum }\end{array}$ & 60 \\
\hline 4 & $\begin{array}{l}\text { Mengelus perut dan } \\
\text { punggung }\end{array}$ & 54 \\
\hline 5 & $\begin{array}{l}\text { Memandu ibu untuk nafas } \\
\text { panjang }\end{array}$ & 60 \\
\hline 6 & Menenangkan ibu & 89 \\
\hline 7 & $\begin{array}{l}\text { Membantu menyampaikan } \\
\text { pesan ibu pada tenaga } \\
\text { kesehatan }\end{array}$ & 80 \\
\hline 8 & $\begin{array}{l}\text { Membantu memposisikan } \\
\text { ibu }\end{array}$ & 69 \\
\hline 9 & Memberi semangat pada ibu & 71 \\
\hline 10 & $\begin{array}{l}\text { Mendampingi ibu selama } \\
\text { Kala II }\end{array}$ & 89 \\
\hline
\end{tabular}

Data tabel 3. diketahui bahwa responden terbanyak pada item "datang ke klinik bersama ibu bersalin" sebanyak $91 \%$ responden sedangkan item terendah pada item "mengelus perut dan punggung" sebanyak 54\% responden.

Nyeri atau cemas ini akan mengakibatkan stress yang berdampak pada peningkatan aktifitas saraf otonom sehingga dapat terjadi peningkatan pelepasan ketokolamin 
maternal yang pada akhirnya dapat menyebabkan penurunan aliran darah uterus. Sebagai salah satu efek samping peningkatan kadar adrenalin adalah penurunan aktifitas uterus yang dapat menyebabkan persalinan pada lama kala I. Penjelasan ini diperkuat oleh suatu hasil studi Chapman (2006) dalam Fajaryani (2015) bahwa respon stress merupakan faktor pertama terjadinya partus lama sedangkan presentasi/ posisi janin, CPD, pembatasan mobilitas dan postur setengah berbaring, puasa ketat, analgesia dan paling jarang penyebab fisik.

Hasil studi terhadap 100 sampel menemukan bahwa $89 \%$ istri ingin didampingi oleh suaminya saat bersalin. Selain itu juga didukung oleh sebuah penelitian yang dilakukan Suwarni (2006) dalam Fajaryani (2015) mengenai hubungan antara dukungan suami dengan kestabilan emosi dalam menghadapi proses persalinan dengan 60 sampel ibu hamil mendapatkan hasil bahwa adanya hubungan positif yang signifikan antara dukungan suami dengan kestabilan emosi dalam menghadapi persalinan. Sumbangan efektif atau peranan dukungan suami terhadap kestabilan emosi dalam menghadapi persalinan.

Hasil penelitian ini didukung oleh penelitian yang dilakukan Yuliastanti (2013) dari hasil analisis daiperoleh proporsi ibu bersalin yang didampingi suami dengan baik saat melahirkan di BPS Siti Lestari sebanyak $56,3 \%$ dan $50 \%$ ibu bersalin mengalami skala nyeri ringan dengan pendampingan suami baik mapupun dengan pendampingan suami kurang baik. Melalui uji statistik dengan $C h i$ Kuadrat dapat dilihat $\mathrm{X}^{2}$ hitung $>\mathrm{X}^{2}$ tabel $(8,381>5,99)$ dan $p$ value sebesar 0,015 berarti ada hubungan pendampingan suami dengan pengurangan rasa nyeri pada persalinan kala I fase aktif.

Hasil penelitian ini sejalan dengan penelitian yang dilakukan oleh Septi (2014) dari total sampling ibu primi para normal di RSIA Bunda Arif Purwokerto yang memenuhi kriteria sebanyak 30 responden. Rata-rata dukungan yang diberikan suami saat persalinan adalah skor 15 dan rata-rata nyeri yang dirasakan ibu bersalin adalah skor 5, sehingga semakin baik dukungan yang diberikan oleh suami saat proses persalinan maka nyeri persalinan semakin berkurang dengan model persamaan. Koefisien regresi sebesar -0,431 menyatakan bahwa setiap penambahan 1 dukungan suami akan mengurangi nyeri persalinan sebesar 0,431. Namun sebaliknya jika dukungan keluarag berkurang 1 maka nyeri juga diprediksi mengalami peningkatan sebesar 0,431. Kesimpulannya adalah semakin baik dukungan yang diberikan oleh suami saat proses persalinan, maka semakin rendah nyeri yang dirasakan ibu ketika proses persalinan.

Penelitian lain yang mendukung dari Tini (2015) dari hasil uji analisis dengan Kendall Tau diperoleh nilai signifikasi sebesar 0,000. Hasil tersebut menunjukkan terdapat hubungan antara pendampingan suami dengan intensitas nyeri persalinan kala I di RS PKU Muhammadiyah Yogyakarta. Nilai $t$ hitung sebesar 0,522 menunjukkan keeratan hubungan sedang dan koefisien korelasi berpola negatif artinya semakin rendah pendampingan suami maka intensitas nyeri persalinan kala I semakin berat. Penelitian serupa oleh Saboe (2015) dengan variabel umur, paritas, dan pendampingan suami dengan intensitas nyeri 
persalinan kala I fase aktif deselerasi di ruang bersalin RSUD Prof. Dr. H. Aloei Saboe Kota Gorontalo. Nilai signifikasi 0,000 menunjukkan adanya kebermaknaan hubungan antara pendampingan suami dengan intensitas nyeri persalinan kala I fase aktif deselerasi ini disebabkan oleh pengaruh psikologis dengan adanya dukungan emosional dari suami dapat mengalihkan perhatian ibu dan menurunkan stressor yang menjadi stimulus nyeri saat bersalin sehingga intensitas nyeri dapat berkurang.

\section{KESIMPULAN}

Karakteristik responden yang memiliki usia dengan rentang 31-35 tahun sebanyak 14 orang (40\%), mayoritas responden merupakan multipara yaitu 19 orang (54,3\%), pendidikan dengan klasifikasi tinggi sebanyak 26 orang $(74,3 \%)$, dan 19 orang $(54,3 \%)$ reponden tidak memiliki pengalaman nyeri persalinan sebelumnya. Hasil uji statistik menunjukkan adanya hubungan antara dukungan suami dan keluarga dengan intensitas nyeri persalinan Kala I dibuktikan dengan p-value $<0,05$ $(0,018)$. Nilai koefisien korelasi ($0,396)$ menunjukkan hubungan yang negatif dimana semakin tinggi dukungan suami dan keluarga maka semakin rendah intensitas nyeri persalinan yang dirasakan oleh ibu bersalin.

\section{UCAPAN TERIMAKASIH}

Peneliti mengucapkan terima kasih kepada LPPM Universitas 'Aisyiyah Yogyakarta yang telah memberikan dana sehingga penelitian ini dapat terlaksana.

\section{DAFTAR PUSTAKA}

Fajaryani, T., Sucipto, E., \& Andari, I. D. (2015). Perbedaan Tingkat Nyeri Persalinan pada Ibu Bersalin Normal Kala I Primigravida dan Multigravida di BPM Ny.M Slerok Kota Tegal Tahun 2014, (09).

Hilmansyah. (2011). Peran Pendamping Selama Proses Persalinan. http://www.askep-askeb.cz.cc diakses tanggal 20 Agustus 2017

Hutahaean. (2009). Asuhan Keperawatan Dalam Maternitas dan Ginekologi. Salemba Medika. Jakarta. Hal. 63

Juwita, S., \& Rahmah, H. (2014). Dukungan dan Partisipasi Suami Saat Persalinan, 1-10. Fakultas Ilmu Kesehatan Universitas Indonesia.

Magfuroh, A. (2012). Faktor-faktor yang Berhubungan Dengan Nyeri Persalinan Kala I Fase Aktif Di Ruang Bersalin Rumah Sakit Umum Kabupaten Tangerang. Universitas Islam Negeri Syarif Hidayatulloh Jakarta.

Maslikhanah. (2011). Penerapan Teknik Pijat Effleurage sebagai Upaya Penurunan Nyeri Persalinan pada Ibu Inpartu kala I Fase Aktif. Tesis. Universitas 11 Maret.

Septi, D., Sumarni, \& Eko, E. (2014). Pengaruh Dukungan Suami Dalam Proses Persalinan Dengan Nyeri Persalinan DI RSIA Bunda Arif Purwokerto. Bidan Prada: Jurnal Ilmiah Kebidanan, 5, No.1, 1-12. Akademi Kebidanan YLLPP Pusrwokerto. 
E. Puspitasari/Jurnal Kesehatan 12 (2) 2019, 118-124

Tini, A., \& Wati, S. (2015). Hubungan Pendampingan Suami Dengan Intensitas Nyeri Persalinan Kala I di RS PKU Muhammadiyah Yogyakarta.

Yuliastuti, T., \& Novita Nurhidayati. (2013). Pendampingan Suami dan Skala Nyeri Pada Persalinan Kala 1 Fase Aktif. Bidan Prada: Jurnal Ilmiah Kebidanan, 4(1), 1-14. 